\title{
Pathophysiological role of calcium channels and transporters in the multiple myeloma
}

\author{
Tingting $\mathrm{Li}^{1,2}$, Junmin Chen ${ }^{1,2^{*}}$ and Zhiyong Zeng ${ }^{1,2^{*}}$ (D)
}

\begin{abstract}
Multiple myeloma (MM) is a common malignant tumor of plasma cells. Despite several treatment approaches in the past two decades, MM remains an aggressive and incurable disease in dire need of new treatment strategies. Approximately $70-80 \%$ of patients with MM have myeloma bone disease (MBD), often accompanied by pathological fractures and hypercalcemia, which seriously affect the prognosis of the patients. Calcium channels and transporters can mediate $\mathrm{Ca}^{2+}$ balance inside and outside of the membrane, indicating that they may be closely related to the prognosis of MM. Therefore, this review focuses on the roles of some critical calcium channels and transporters in MM prognosis, which located in the plasma membrane, endoplasmic reticulum and mitochondria. The goal of this review is to facilitate the identification of new targets for the treatment and prognosis of MM.
\end{abstract}

Keywords: Plasma membrane $\mathrm{Ca}^{2+}$ transporters, Store-operated $\mathrm{Ca}^{2+}$ entry, Mitochondrial $\mathrm{Ca}^{2+}$ transporters, Myeloma bone disease, Prognosis

\section{Introduction}

Multiple myeloma (MM), a malignant tumor with abnormal accumulation of terminally differentiated plasma cells, is the second most common hematologic cancer after lymphoma $[1,2]$. Most patients with MM will have varying degrees of bone destruction [3], renal insufficiency and hypercalcemia [4], which is closely related to calcium regulation. Studies have confirmed that serum calcium level reflects the ability of bone resorption and bone formation [5]. Hypercalcemia is an adverse prognostic factor in MM [6], and it is most common in those myeloma patients who have the greatest tumor volume or patients with plasma cell leukemia (a late stage complication of myeloma) [7]. The reasons for this are still unclear, but they may be related to bone resorption activity produced by myeloma cells and glomerular filtration status. Because myeloma patients often have irreversible kidney

\footnotetext{
*Correspondence: drjunminchen@hotmail.com; zengzhiyong049@163.com ${ }^{1}$ Department of Hematology, The First Affiliated Hospital of Fujian Medical University, 20 Chazhong Road, Fuzhou, Fujian 350005, People's Republic of China

Full list of author information is available at the end of the article
}

damage and increased renal tubular calcium reabsorption, resulting in elevated serum calcium concentration and abnormal bone remodeling $[7,8]$. In addition, previous studies have reported that the interaction between MM cells and osteoclasts accelerates bone destruction and bone remodeling in myeloma, which leads to an increase in calcium concentration in serum and bone marrow $[7,9]$. Therefore, MM cells may be exposed to a high concentration of extracellular calcium in the bone marrow microenvironment, but so far, the relevant calcium transporters/channels and mechanisms of calcium regulation in MM are still unclear.

Calcium channels and transporters are protein structures that exist in cell membranes, endoplasmic reticulum membranes, and mitochondrial membranes. They can mediate $\mathrm{Ca}^{2+}$ balance inside and outside of the membrane, thus maintaining the physiological functions of the organism. The network control of calcium channels and transporters which regulate intracellular $\mathrm{Ca}^{2+}$ homeostasis includes: (1) calcium channels or transporters that allow $\mathrm{Ca}^{2+}$ influx from extracellular $\mathrm{Ca}^{2+}$ storage across the plasma membrane (PM), such as transient receptor potential channel (TRP), G Protein-Coupled Receptors original author(s) and the source, provide a link to the Creative Commons licence, and indicate if changes were made. The images or other third party material in this article are included in the article's Creative Commons licence, unless indicated otherwise in a credit line to the material. If material is not included in the article's Creative Commons licence and your intended use is not permitted by statutory regulation or exceeds the permitted use, you will need to obtain permission directly from the copyright holder. To view a copy of this licence, visit http://creativecommons.org/licenses/by/4.0/. The Creative Commons Public Domain Dedication waiver (http://creativeco mmons.org/publicdomain/zero/1.0/) applies to the data made available in this article, unless otherwise stated in a credit line to the data. 
(GPCRs) and purinergic receptor (ATP-gated cation channel P2X7 receptor); (2) Inositol 1,4,5-triphate receptor (IP3R) or ryanodine receptor (RyR) and stromalinteraction molecule1 (Stim1) combined with the plasma membrane calcium channel protein Orai1 (also known as CRACM1) to mediate $\mathrm{Ca}^{2+}$ release from the endoplasmic/sarcoplasmic reticulum (ER/SR); (3) Mitochondrial Voltage-Dependent Anion Channel 1 (VDAC1) and $\mathrm{Ca}^{2+}$ uniporter $(\mathrm{MCU})$ regulate mitochondrial $\mathrm{Ca}^{2+}$ uptakes; (4) $\mathrm{Ca}^{2+}$-ATPase pumps $\mathrm{Ca}^{2+}$ from cytoplasm back to ER/SR or extracellular space [10, 11] (Fig. 1). Most features of cancer, if not all, involve calcium signaling to mediate critical cellular processes, including transcriptional regulation, which underlies the gene expression in a variety of pathways essential for tumorigenesis and metastasis [12]. So far, various studies have shown that changes in calcium channels and transporters are related to the proliferation, apoptosis, osteoclast differentiation and outcome of MM. For instance, the knockdown of the non-selective cation channel TRP proteins, known as a type of calcium channel on the cell membrane, was shown to result in the differentiation of osteoclast in MM $[13,14]$. Purinergic receptor P2X7 activation induces cell death in human RPMI 8226 multiple myeloma cells [15]. Up-regulation of Stim1 or Orai1 [two critical regulators of Store-Operated $\mathrm{Ca}^{2+}$ Entry (SOCE)] was associated with the clinical outcome of MM, and Stim1 or Orai1 down-regulation reduce cell viability, cause cell apoptosis and cell cycle arrest in MM cell lines [16]. In human CD45 ${ }^{+}$U266 myeloma cells, VDAC1 might sensitize to many extracellular stimuli that trigger apoptosis via the mitochondrial pathway [17].

Therefore, in this review, we summarize the expression, localization and pathophysiological role of some essential calcium channels and transporters, including the transient receptor potential channel (TRP) family, GPCR family, Purinergic receptors, SOCE channels and Mitochondrial $\mathrm{Ca}^{2+}$ transporters, which have been reported to be altered in MM (Fig. 2, Table 1).

\section{Plasma membrane $\mathrm{Ca}^{2+}$ channels TRP channels}

The TRP superfamily channels consist of many nonselective cation channels, including more than 30 members and can be further divided into seven subgroups, i.e. TRPV (vanilloid), TRPC (canonical), TRPM (melastatin),

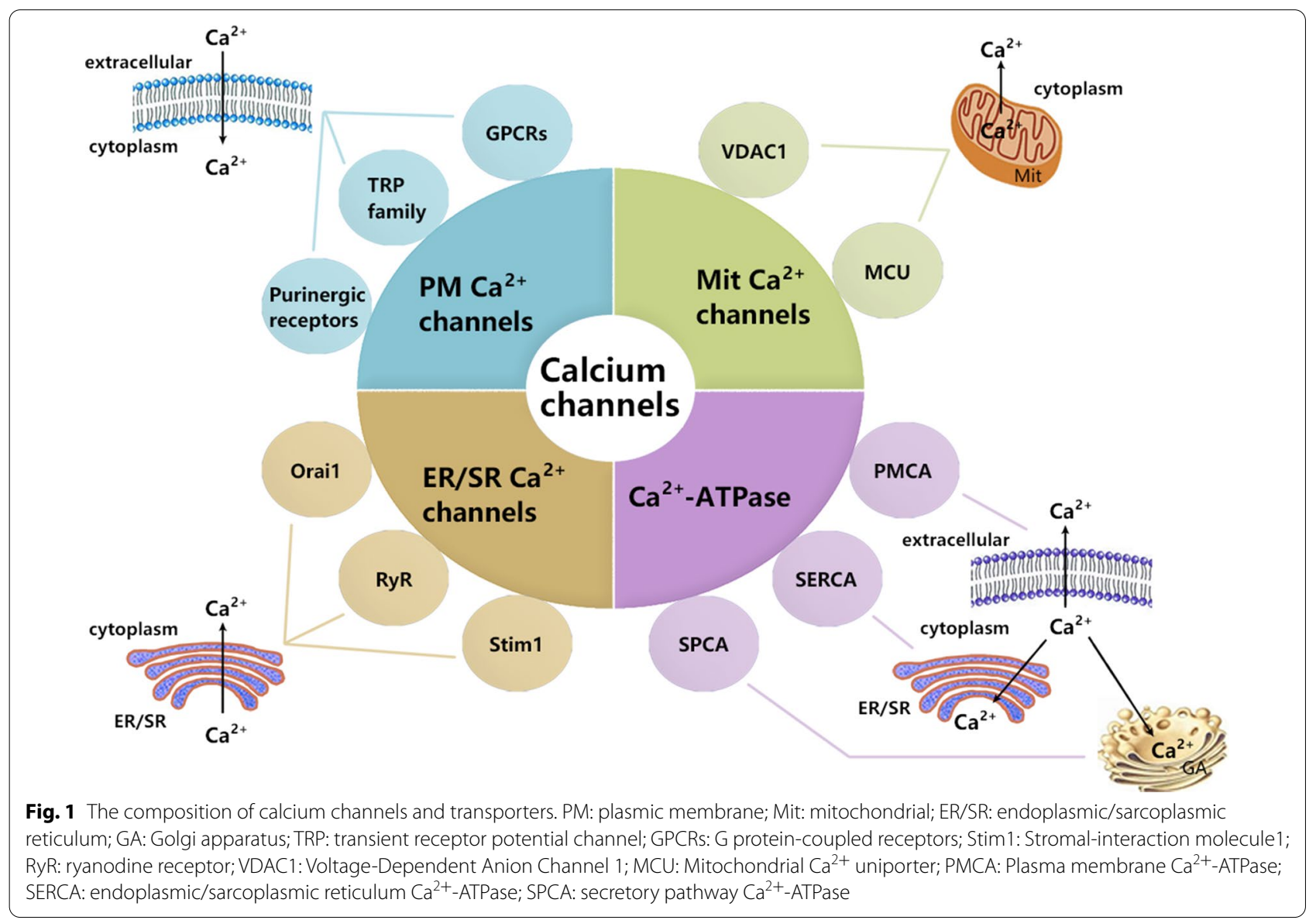




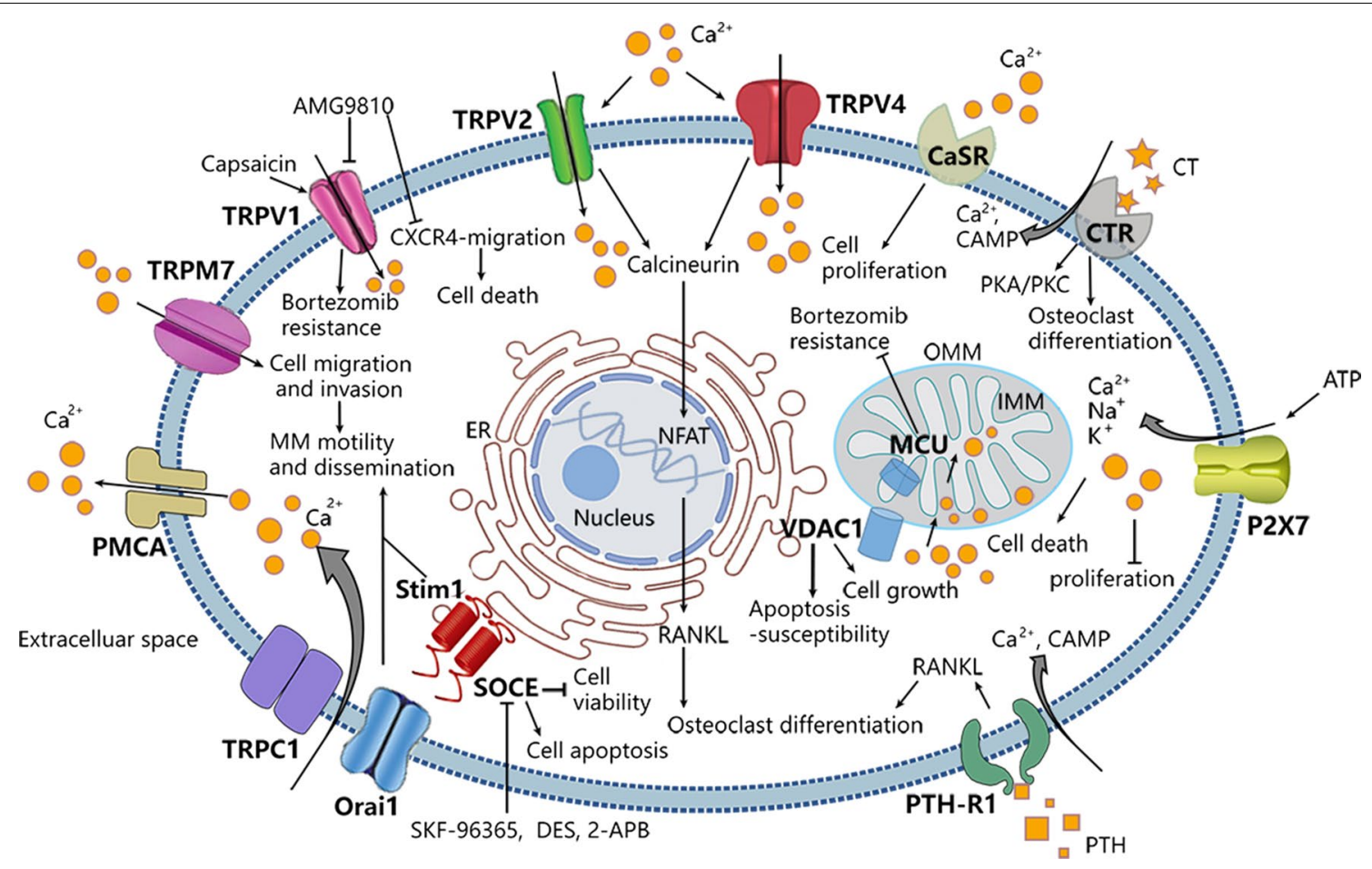

Fig. 2 Important $\mathrm{Ca}^{2+}$ channels/transporters in multiple myeloma cells. ER: Endoplasmic reticulum; OMM: Outernal mitochondrial membranes; IMM: internal mitochondrial membranes. The intracellular $\mathrm{Ca}^{2+}$ is governed by a series of proteins: (1) plasma membrane $\mathrm{Ca}^{2+} \mathrm{channels}$ or transporters, such as TRPs (TRPV1, TRPV2, TRPV4, TRPM7), G Protein-Coupled Receptors (CaSR, CTR, PTH-R1), Purinergic receptors (P2X7), which mediate $\mathrm{Ca}^{2+}$ influx into cells. (2) Store-Operated $\mathrm{Ca}^{2+}$ Entry, as one of the major pathways for $\mathrm{Ca}^{2+}$ influx across plasma membrane. (3) Mitochondrial $\mathrm{Ca}^{2+}$ transporters, including VDAC1 and $\mathrm{MCU}$, mediate $\mathrm{Ca}^{2+}$ transport across internal and outernal mitochondrial membranes. (4) $\mathrm{Ca}^{2+}$-ATPases pumping $\mathrm{Ca}^{2+}$ from cytosol to extracellular space. $\mathrm{Ca}^{2+}$ can regulate various cellular events, including gene transcription, proliferation, migration and apoptosis. During development of multiple myeloma, the alteration of $\mathrm{Ca}^{2+}$ channels/transporters lead to changes in $\mathrm{Ca}^{2+}$ permeability and distribution inside and outside the cell membrane as well as activation of various signaling pathways, providing a suitable microenvironment for the growth of tumor cells. Targeting the dysregulated $\mathrm{Ca}^{2+}$ channels/transporters may improve the prognosis of patients with MM

TRPML (mucolipin), TRPP (polycystic), TRPN (no mechanoreceptor potential C), and TRPA (ankyrin) [18]. Each subgroup contains several channel subtypes, which have different $\mathrm{Ca}^{2+}$ selectivity, activation mechanisms and interacting proteins [19]. These channels consist of six transmembrane domain segments (S1-S6) and intracellular carboxy $(\mathrm{C}-)$ and amino $(\mathrm{N}-)$ termini in the pore region between S5 and S6 [20]. TRP family is one of the leading calcium channels [21], which regulates intracellular $\mathrm{Ca}^{2+}$ concentration and plays a vital role in various physiological functions, including mediating pain transmission, bone metabolism, and tumor occurrence and metastasis [22, 23]. For example, the TRPV family is related to the onset and progression of MM and chronic myeloid leukemia [24]. The TRPM family, especially TRPM7, has been shown to regulate B cell development and antigen recognition [25]. The TRPC family is involved in the occurrence and development of acute T-cell leukemia tumors [26]. Next, we aim to outline the role of TRPV and TRPM ion channels in MM, and the role of TRPC in MM will be introduced in the part of endoplasmic reticulum SOCE.

TRPV channel structures have six highly conserved transmembrane domain architecture. The functional TRPV channels are tetrameric assemblies that surround a central permeation pathway [27]. The six members of TRPV family can be further divided into three distinct groups based on functional characteristics: fairly nonselective cation channels TRPV1-3 [28], cation-selective efflux channel TRPV4 [29], and epithelial channels TRPV5 and TRPV6 [30, 31]. In TRPV family, studies have reported the importance of TRPV1, TRPV2, and TRPV4 in MM.

TRPM family is the largest and most diverse subfamily in the TRP superfamily [32], composed of eight members, TRPM1 to TRPM8. The TRPM channels have a large cytosolic domain with 732-1611 amino acids for per subunit [33]. Most of the TRPM channels are nonselective $\mathrm{Ca}^{2+}$ permeable cation channels; only TRPM4 and TRPM5 are impermeable to $\mathrm{Ca}^{2+}[34,35]$. In this 
Table 1 Expression, localization and phthophysiological function of calcium channels and transporters in MM

\begin{tabular}{|c|c|c|c|c|c|c|}
\hline Name & $\begin{array}{l}\text { Related } \\
\text { channels/ } \\
\text { transporters }\end{array}$ & Main localization & Compound & Mechanism & $\begin{array}{l}\text { Pathophysiological role } \\
\text { in MM }\end{array}$ & References \\
\hline \multirow[t]{3}{*}{ TRPVs } & TRPV1 & Plasma membrane & Capsaicin & Activator & $\begin{array}{l}\text { TRPV1 inhibitor has syner- } \\
\text { gistic anti-MM activity with } \\
\text { bortezomib }\end{array}$ & [47] \\
\hline & TRPV2 & Plasma membrane & SKF96365 & Inhibitor & $\begin{array}{l}\text { TRPV2 promotes osteoclast } \\
\text { differentiation }\end{array}$ & [13] \\
\hline & TRPV4 & Plasma membrane & - & - & $\begin{array}{l}\text { TRPV4 activation promotes } \\
\text { osteoclast differentiation } \\
\text { and bone resorption }\end{array}$ & {$[60]$} \\
\hline TRPMs & TRPM7 & Plasma membrane & - & - & $\begin{array}{l}\text { TRPM7 regulates MM cell } \\
\text { motility and dissemination }\end{array}$ & {$[68]$} \\
\hline \multirow[t]{3}{*}{ GPCRs } & CaSR & Plasma membrane & $\begin{array}{l}\mathrm{CaCl}_{2} \\
\text { Gadolinium } \\
\text { Neomycin }\end{array}$ & $\begin{array}{l}\text { Activator } \\
\text { Activator } \\
\text { Activator }\end{array}$ & $\begin{array}{l}\text { CaSR promotes the mitosis } \\
\text { of MM cells }\end{array}$ & [57] \\
\hline & CTR & Plasma membrane & Calcitonin & Activator & $\begin{array}{l}\text { CTR inhibits bone resorp- } \\
\text { tion by neutralizing OC } \\
\text { migration and shape } \\
\text { retraction, and may par- } \\
\text { ticipate in the osteoclast } \\
\text { differentiation of MM }\end{array}$ & $\begin{array}{l}{[85]} \\
{[89]}\end{array}$ \\
\hline & PTH-R1 & Plasma membrane & PTHrP & Activator & $\begin{array}{l}\text { PTHrP stimulates the secre- } \\
\text { tion of PTH-R1, promotes } \\
\text { proliferation of MM cells } \\
\text { and the production of } \\
\text { osteoclastogenesis factors }\end{array}$ & $\begin{array}{l}{[90]} \\
{[92]}\end{array}$ \\
\hline Purinergic receptors & $\mathrm{P} 2 \mathrm{X7}$ & Plasma membrane & ATP & Activator & $\begin{array}{l}\text { Activation of } \mathrm{P} 2 \times 7 \text { may } \\
\text { induce the apoptosis and } \\
\text { prevent the proliferation of } \\
\text { MM cells }\end{array}$ & {$[15]$} \\
\hline \multirow[t]{5}{*}{ SOCE } & Stim1 & Plasma membrane, & $\begin{array}{l}\text { SKF-96365 } \\
\text { DES } \\
2 \text {-APB }\end{array}$ & $\begin{array}{l}\text { Inhibitor } \\
\text { Inhibitor } \\
\text { Inhibitor }\end{array}$ & $\begin{array}{l}\text { Silencing Stim1 reduces } \\
\text { cell viability, leading to } \\
\text { apoptosis and cell cycle } \\
\text { arrest of MM cells, and the } \\
\text { high expression of Stim1 } \\
\text { affects the clinical outcome } \\
\text { of MM. In addition, Stim1 } \\
\text { could regulate the motility } \\
\text { and dissemination of dif- } \\
\text { fuse large B-cell lymphoma } \\
\text { (DLBCL) cells and MM cells }\end{array}$ & $\begin{array}{l}{[16]} \\
{[68]} \\
{[126]}\end{array}$ \\
\hline & & Endoplasmic reticulum & & & & \\
\hline & Orai1 & Plasma membrane, & $\begin{array}{l}\text { SKF-96365 } \\
\text { DES } \\
2-A P B\end{array}$ & $\begin{array}{l}\text { Inhibitor } \\
\text { Inhibitor Inhibitor }\end{array}$ & $\begin{array}{l}\text { Silencing Orai1 reduces } \\
\text { cell viability, leading to } \\
\text { apoptosis and cell cycle } \\
\text { arrest of MM cells. And } \\
\text { Orai1 regulates the motility } \\
\text { and dissemination of dif- } \\
\text { fuse large B-cell lymphoma } \\
\text { (DLBCL) cells and MM cells }\end{array}$ & $\begin{array}{l}{[16]} \\
{[68]} \\
{[111]} \\
{[126]}\end{array}$ \\
\hline & & Cytosol & $\mathrm{AnCoA4}$ & & & \\
\hline & TRPC1 & Plasma membrane & - & - & $\begin{array}{l}\text { Knockout of TRPC1 inhibits } \\
\text { the death of MM cells }\end{array}$ & [132] \\
\hline \multirow[t]{2}{*}{$\begin{array}{l}\text { Mitochondrial } \mathrm{Ca}^{2+} \text { trans- } \\
\text { porters }\end{array}$} & VDAC1 & $\begin{array}{l}\text { Mitochondrion, } \\
\text { Nucleus }\end{array}$ & - & - & $\begin{array}{l}\text { VDAC1 promotes the } \\
\text { growth of MM cells, accel- } \\
\text { erates the development } \\
\text { of MM, and affects the } \\
\text { prognosis ofpatients }\end{array}$ & $\begin{array}{l}{[17]} \\
{[144]}\end{array}$ \\
\hline & MCU & Mitochondrion & Ruthenium red & Inhibitor & $\begin{array}{l}\text { MCU can reduce MM } \\
\text { bortezomib resistance and } \\
\text { promote MM cell apoptosis }\end{array}$ & $\begin{array}{l}{[151]} \\
{[152]}\end{array}$ \\
\hline
\end{tabular}


part, we mainly discuss the role of TRPM7 in MM tumorigenesis.

\section{TRPV1 channel}

TRPV1 is the first member of the TRPV family, which respond to low $\mathrm{pH}$ value $(<5)$, capsaicin noxious heat $\left(>43{ }^{\circ} \mathrm{C}\right)$ and so on $[36,37]$. TRPV1 was initially discovered in rat dorsal root ganglion [38], and involved in the regulation of calcium signaling, inflammation and metabolism, and was closely related to cancer [39, 40]. The functional expression of TRPV1 has been confirmed in several human malignancies including breast, prostate, urothelial cancer and glioma [41-44], yet remained largely unknown in hematologic malignancies especially in MM. At present, drug resistance remains a major challenge for MM cure and calcium signaling was proposed to play a role in drug resistance of cancer cells [45]. TRPV1 has been recognized as an important regulator of intracellular calcium levels, and it was found to be highly expressed in MM cell lines (RPMI8226, INA6 and MM.1S) in a chip analysis of GSE5900 and GSE2658. Recently, a study proposed the role of TRPV1 in MM tumor progression and bortezomib resistance. It is known that induction of endoplasmic reticulum (ER) stress is one of the main mechanisms of bortezomibmediated cell death. In response to ER stress conditions, the unfolded protein response (UPR) signaling cascade is activated to counteract the occurring damage [46]. Beider et al. found that TRPV1 inhibition (using a pharmacological inhibitor AMG9810) resulted in calcium-dependent accumulation of mitochondrial reactive oxygen species (ROS), followed by mitochondrial instability and MM cell death [47]. These results are consistent with previous findings, indicating that calcium is a key regulator of mitochondrial function, and that calcium overload can impair electron transport leading to ROS generation [48]. In addition, TRPV1 inhibitor (AMG9810) interferes with calcium signaling and suppresses chemokine receptor CXCR4 (CXC-Motif Receptor 4)-mediated migration and stromal protection. It acts synergistically with bortezomib to target ubiquitin pathway and cytoprotective mitochondrial UPR, impairs mitochondria, destabilizes lysosome and promotes MM cell death. On the contrary, TRPV1 agonist (capsaicin) promotes calcium influx, resulting in transient increase in cytosolic calcium levels, thus supporting CXCR4-mediated activity [47]. Importantly, the combination of TRPV1 inhibitor (AMG9810) and bortezomib showed superior anti-MM activity in vivo model of CXCR4-driven human MM engrafting in murine bone marrow [47]. Altogether, these results reveal the mechanism mediating the synergistic anti-MM activity of bortezomib in combination with TRPV1 inhibition which may be translated into clinical practice.

\section{TRPV2 channel}

TRPV2 is widely expressed in different cells and tissues [49], such as B lymphocyte [50], $\mathrm{CD}^{34+}$ hematopoietic stem cells [51], and is a $\mathrm{Ca}^{2+}$ permeable channel that contributes to calcium homeostasis [28]. TRPV2 expression in some tumor cells is significantly higher than that in normal cells [52-54], and according to the Cancer Cell Line Encyclopedia (CCLE) database, the expression of TRPV2 is higher in MM cell lines compared to other tumor cell lines. In the study of TRPV2 expression, the protein was detected to be highly expressed in MM patient and MM cell lines (ARP-1, LP-1) by Immunohistochemistry and Western-blot analysis technology, indicating that TRPV2 played a role in MM development [13]. Numerous studies have shown that TRPV2 expression is related to tumor prognosis. In bladder cancer, TRPV2 promotes tumor cell migration and invasion through metalloproteinase 2 (MMP2) [55]; in oesophagal squamous cell carcinoma, high expression of TRPV2 has confirmed to be related to the patient's disease stage and overall survival [56]. Bai et al. analyzed public gene expression data of bone marrow plasma cells from GSE24080. They found that MM patients with asymptomatic survival and overall survival less than 24 months, the transcriptional level of TRPV2 was significantly higher than that in patients with approximately 24 months [13]. In addition, TRPV2 is related to the occurrence of bone lesions in MM. Myeloma cells often expose to high levels of extracellular calcium concentrations $\left(\mathrm{Ca}_{\mathrm{o}}{ }^{2+}\right)$ in the microenvironment surrounding destructive bone lesion [57]. Laboratory studies have shown that a high concentration of $\mathrm{Ca}_{\mathrm{o}}{ }^{2+}$ could increase the expression of TRPV2 in ARP-1 and LP-1 cell lines. TRPV2 up-regulates intracellular calcineurin protein, promoting the dephosphorylation of NFATc3 and accelerating NFATc3 to enter the nucleus, thereby enhancing the synthesis and secretion of osteoclast-related factors (such as Receptor Activator of Nuclear Factor-к B Ligand (RANKL)) in MM cells, ultimately leading to MBD [13]. SKF96365, an inhibitor of TRPV2, proved to be able to inhibit RANKL-mediated osteoclast differentiation, suggesting that SKF96365 may be used as a new type of treatment for MBD [13].

\section{TRPV4 channel}

TRPV4, a $\mathrm{Ca}^{2+}$-permeable channel of the TRP family, regulates the homeostasis of intracellular calcium concentrations $\left(\mathrm{Ca}_{\mathrm{i}}{ }^{2+}\right)$ [58]. It mediates $\mathrm{Ca}^{2+}$ influx in the late stage of osteoclast differentiation, thus regulating $\mathrm{Ca}^{2+}$ signal, which is crucial for cellular events during osteoclast differentiation [59]. MM patients often accompany by abnormal bone metabolism, and the occurrence 
of MBD is related to the differentiation of osteoclasts [13]. Studies have shown that TRPV4 gene knocked out mice increase bone mass by impairing bone resorption, and TRPV4 activation promotes osteoclast differentiation and bone resorption [60]. In recent years, autophagy has been reported not only as an essential mechanism for maintaining cell homeostasis but also play a vital role in the regulation of osteoclastogenesis [61]. Cao and his colleagues found that TRPV4 up-regulated autophagyrelated proteins and $\mathrm{Ca}^{2+}$-calcineurin-NFATc1 signaling, thereby promoting the secretion of osteoclast-related factors and modulating osteoporosis [14]. In summary, TRPV4 can be used as a potential therapeutic target for $\mathrm{MBD}$ and other bone resorption diseases.

\section{TRPM7 channel}

TRPM7 is an ion channel that regulates cellular magnesium and calcium homeostasis [62], though it specifically promotes $\mathrm{Ca}^{2+}$ influx in various cancer cells [63, 64]. TRPM7 is essential for embryonic development, and deletion of TRPM7 in the chicken B cell line DT40 results in growth arrest and cell death [65]. Earlier, Krishnamoorthy et al. demonstrated for the first time that TRPM7 can regulate B cell development and antigen recognition [25], suggesting its role in MM tumorigenesis.

Recently, growing evidence has demonstrated that $\mathrm{MM}$ originates from $\mathrm{BM}$ and disseminates throughout the body (also called extramedullary MM), which are closely correlated with poor prognosis with an overall survival period of less than 6 months $[66,67]$. It is generally believed that the BM microenvironment provides support for MM cell growth and survival and for the acquisition of aggressive phenotypes. High $\mathrm{Ca}^{2+}$ and altered $\mathrm{Ca}^{2+}$ signals in the $\mathrm{BM}$ microenvironment may be a key contributing factor to the pathological process [68]. Therefore, $\mathrm{Ca}^{2+}$ channels and transporters, which are molecular participants of $\mathrm{Ca}^{2+}$ homeostasis, could be significantly involve with MM progression in term of MM cell motility and dissemination. Samart et al. observed that the expression of $\mathrm{Ca}^{2+}$ influx channels (such as TRPM7) in patient-derived MM cells are upregulated compared with normal plasma cells in a bioinformatics database. They used the CRISPR/Cas9 system to repress TRPM7 gene expression in MM cells, which can significantly inhibit the migration and invasion of $\mathrm{MM}$ cells [68]. Such result can reduce the intravasation of MM cells from the BM into nearby blood vessels and for their subsequent extravasation into distant tissues [69, 70]. In addition, vitro and vivo experiments show that TRPM7, Orai1 and Stim1 (Orai1 and Stim1 will be described in detail in SOCE) mediated $\mathrm{Ca}^{2+}$ influx regulate MM cell motility and dissemination by orchestrating O-GlcNAylation homeostasis that targets integrin $\alpha 4$ and integrin $\beta 7$
[68]. In summary, TRPM7 is a key regulator of MM cell motility and dissemination, and may be a potential predictive biomarker and therapeutic targets for advanced MM. Further studies on the role of novel TRPM7 small molecule inhibitors in disseminated MM xenograft models in vivo may be beneficial to future MM treatments to achieve long-term disease control.

\section{G protein-coupled receptors (GPCRs)}

GPCRs are the largest family of membrane signaling proteins in the human body. The core structure of all GPCRs are very similar: 7 transmembrane helix domains, extracellular $\mathrm{N}$-terminus, and intracellular C-terminus [71]. There are two extra-membrane loops (Loop) and three intra-membrane loops. The C-terminus and the intracellular loop connecting the fifth and sixth transmembrane helices have binding sites for protein $\mathrm{G}$ (guanylate binding protein). Most GPCRs belong to class A [71], which are rhodopsin-like receptors. Class B GPCRs can interact with peptides. Class C GPCRs are dimers composed of two 7 TM units, which are homologous to bacterial proteins involved in the transport of amino acids and ions [72]. And there are no receptors belong to class D, $\mathrm{E}, \mathrm{F}$ or $\mathrm{O}$ in the human genome [71]. GPCRs usually localize on the plasma membrane, which mediates the response of cells to various stimuli, ultimately cause cellular responses [73]. Here, we mainly explain the role of GPCRs in the $\mathrm{Ca}^{2+}$ transport process.

\section{Calcium sensitive receptor (CaSR)}

Calcium-Sensing Receptor (CaSR) is a class C GPCRs discovered in 1993 by Brown and coworkers [74]. It is widely distributed in the human body and participates in numerous physiological and pathological processes, monitoring extracellular $\mathrm{Ca}^{2+}$ concentration and responding to various signals stimulate, and then regulating $\mathrm{Ca}^{2+}$ homeostasis [74]. CaSR is a homodimer, and each monomer composes an $\mathrm{N}$-terminal extracellular domain (ECD), a seven-transmembrane domain (TTM) and an intracellular C-tail domain (C-tail) [75]. $\mathrm{Ca}^{2+}$ is the primary agonist of CaSR and can bind to the ECD region [76], and is thought to be involved in regulating mitotic transitions [77]. Yamaguchi et al. found that CaSR can promote the mitogenic response of mouse osteoblastic MC3T3-E1 cell [78]. CaSR agonists (such as $\mathrm{Ca}^{2+}$, gadolinium $\left(\mathrm{Gd}^{3+}\right)$, and neomycin) increased levels of inositol triphosphate (IP3), cytosolic calcium concentration and DNA synthesis through a mechanism coupled to the activation of $\mathrm{G}$ protein and PKC [74, 79]. Besides, the mitogen-activated protein kinase (MAPK) family members, p42/44 and p38 MAPK, have been confirmed to be involved in CaSR-stimulated mitogenic response in mouse osteoblastic MC3T3-E1 cell. These responses may 
serve to ensure the availability of adequate numbers of osteoblastic cells at sites of recent bone resorption [80]. $\mathrm{MM}$ often accompanies by an increase in $\mathrm{Ca}_{\mathrm{o}}{ }^{2+}$, which leads to changes of CaSR expression in hematopoietic precursor cells, and ultimately red blood cell precursors, megakaryocytes (the precursors of blood platelets), monocytes, and macrophages, all of which express higher levels of the CaSR than white blood cells precursors [81]. In human myeloma cells, such as U266, IM-9 and RPMI8226 cells, exposure to high $\mathrm{Ca}^{2+}$ concentration augmented cell proliferation through CaSR on their surfaces, and further participate in a vicious cycle by expanding myeloma cell mass in destructive bone lesions [57]. Studies have reported that some basal or constitutive activity of MAPK, Interleukin-6 (IL-6), insulin-like growth factor-1 (IGF-1) or other signaling pathways have been found in these myeloma cells, which can promot cell proliferation $[82,83]$. This is how myeloma cells survive in bone marrow microenvironment, indicating that CaSR, at least in part, might mediate these survival signals to regulate the mitosis of myeloma cells. However, CaSR activators (such as $\mathrm{Ca}^{2+}$, NPS, R467) did not enhance IL-6 expression in these cells, indicating that CaSR agonists exerting a mitogenic effect on myeloma cells seemed to be independent of IL-6 actions [57]. In addition, CaSR agonists have shown to stimulate proliferation of osteoblasts, monocyte-macrophages, bone marrow stromal cells and fibroblasts [57], which further supports the view that CaSR activation can promote MM mitosis.

\section{Calcitonin receptor (CTR)}

Calcitonin receptor (CTR) belonged to class B GPCR and identified originally in porcine kidney epithelial cell line [84]. CTR primarily expressed in osteoclasts (OCs), K562 myeloid leukemia cells, human breast cancer, kidney, and mouse and human lymphocytes, with a down-regulating effect on its function in response to hypercalcemia [85]. CTR contains seven transmembrane regions, four extracellular loops (ECL1-4) and four intracellular loops. It has proved that the ECL2 and ECL3 region are the binding sites of calcitonin (CT) [86]. Six structural variants have described, i.e. CTR-1 to -6 isoforms with most unknown functions. CTR structural isoforms can activate several heterotrimeric $\mathrm{G}$ proteins in response to $\mathrm{CT}$ stimulation, trigger various signal transduction mechanisms, that lead to intracellular $\mathrm{Ca}^{2+}$ isoform or adenylate cyclase accumulation throughout PKC or PKA pathway, respectively [87]. The CTR-2 isoform was detected on Ocs, with 16 amino acid deletions in the first intracellular loop [88]. Its main functions include the inhibition of bone resorption by neutralizing OCs migration and a shape retraction [89]. Silvestris et al. have shown that myeloma cell lines
(U-266, MCC-2 and RPMI 8226 cells) express CTR-2 isoform and activate both cAMP and $\mathrm{Ca}^{2+}$ flow, suggesting the activation of PKA and PKC pathways. In addition, in myeloma cells, CT effectively inhibits bone resorption in vitro, supports the OC-like behavior of myeloma cells, indicating that CT or CTR may participate in the osteoclast differentiation of MM [85].

\section{Parathyroid hormone-related protein Receptor (PTH-R1)}

Parathyroid hormone-related protein (PTHrP) is functionally similar to parathyroid hormone (PTH), which is the main regulator of $\mathrm{Ca}^{2+}$ homeostasis and an $\mathrm{OC}$ activator. The NH2 terminal fragment of PTHrP can bind to PTH-R1, resulting in a significant increase in intracellular $\mathrm{Ca}^{2+}$ influx [90]. PTH-R1 is mainly distributed in bones and kidneys, and belongs to class B GPCRs. The receptor has seven transmembrane regions, longer extracellular amino acids, and contains more than three pairs of disulfide bonds folded into a network. The extracellular region cooperates with the helical structure of the transmembrane area and participates in the binding of ligands, and PTHrP is the only known PTH-R1 endogenous ligand [91]. There is little information about the role of PTH-R1 in MM. Previous studies reported that PTH-R1 highly expressed in bone marrow plasma cells of MM patients and MM cell lines, and PTHrP stimulated PTH-R1 in MM cells, promoting the proliferation of MM cells, and eventually the increase of $\mathrm{Ca}^{2+}$ influx, CAMP content [92]. Cafforio used ELISA and flow cytometry to demonstrated that in U266, MUS and RPMI 8226 cells, PTH-R1 directly participated in reinforcing both RANKL and monocyte chemoattractant protein 1 (MCP-1) production, while the opposite effect could be observed after PTH-R1 silenced [92]. The above results have clarified that PTHrP promotes MM tumor biological behavior and development through autocrine or paracrine stimulation of PTH-R1, thereby reinforcing the production of osteoclastogenic factors. In addition, they further verified that the PTHrP NH2 fragment (aa 1-40) reacted with PTHR1 in RPMI 8226 cells, but not the NLS-middle region (aa 67-86), NLS middle region (aa 38-94) and $\mathrm{COOH}$ end (aa 107-139) fragments. PTH-R1 systematic analysis is still needed in MM patients to determine whether the receptor is a new marker of disease progression.

\section{Purinergic receptors}

Purinergic receptors, namely P1 and P2 receptors, are widely expressed in mammalian cells and are involved in several physiological functions like nociception, platelet aggregation, inflammatory reaction etc. [93]. The P2 receptors are divided into two groups: P2X and P2Y, each containing some members with different ion selectivity and regulatory properties. The $\mathrm{P} 2 \mathrm{X}$ receptors have a 
trimeric topology with two transmembrane domains. The $\mathrm{P} 2 \mathrm{X} 7$ receptor is a member of P2X, mainly expressed in bones, epithelial cells and normal B lymphocytes [94]. ATP can activate P2X7, leading to the absorption of cations such as $\mathrm{Ca}^{2+}, \mathrm{Na}^{+}$and $\mathrm{K}^{+}$[95]. Low activation of P2X7 receptor promotes cell division, while an acute stimulation by massive ATP causes cell death [96]. For instance, activation of P2X7 in chronic lymphocytic leukaemia (CLL) results in cell death $[97,98]$ and induces the rapid release of cell-surface CD23 from CLL B lymphocytes [99]. CD23 is a 'low affinity', transmembrane receptor for IgE that can be shed from the cell surface to form soluble CD23 (sCD23), which also binds IgE and exerts cytokine-like activities on $\mathrm{B}$ cells and other leukocytes [100]. sCD23 maintains B-cell precursors growth, promotes $\mathrm{B}$ and $\mathrm{T}$ cell differentiation, and drives monocytes to release cytokines [101]. Compared with the plasma sCD23 levels of normal individuals, the sCD23 concentration of CLL patients may be 5 to 300-flod higher [102]. In addition, individuals with low plasma sCD23 concentrations have a more positive prognosis than those with high sCD23 concentrations [103].

Although P2X7 receptor is playing a role in neoplasia, long-term lack of malignant cell lines expressing this receptor, resulting in progress limited of P2X7 receptor in tumorigenesis. In recent years, Farrell et al. found functional P2X7 on the RPMI 8226 MM cell line. In this studies, P2X7 activation-induced death of RPMI 8226 cells, prevented the proliferation of RPMI 8226 cells and also generated CD23 shedding from myeloma cells [15]. As a useful marker in either diagnosis or prognosis of disease [104-106], sCD23 can provide useful value for further study of the mechanism of P2X7 in myeloma. In addition to P2X7, RT-PCR also showed that P2X4 and P2X5 are high expressions and $\mathrm{P} 2 \mathrm{X} 1$ is low expression in RPMI 8226 cells, but it is still unknown whether these mRNAs are translated to proteins or lead to functional P2X channels [15]. At present, the physiological and pathophysiological effects of P2X in myeloma remain unclear and requires further research to elucidate.

\section{Store-operated $\mathrm{Ca}^{2+}$ entry (SOCE)}

Store-Operated $\mathrm{Ca}^{2+}$ Entry (SOCE), as a calcium ion channel, has been widely recognized as one of the major pathways for $\mathrm{Ca}^{2+}$ influx across PM of cells $[107,108]$. The main components of SOCE are Stim proteins and Orai proteins (also known as CRAC). Stim proteins, located in the ER, are single-pass transmembrane proteins. Their EF-hand motif of $\mathrm{N}$-terminal domain serves as a $\mathrm{Ca}^{2+}$ sensor within the ER [109]. In response to ER $\mathrm{Ca}^{2+}$ depletion, Stim proteins undergo a conformational change, forming self-aggregation and CRAC channels at the ER-PM junction through a diffusion trap mechanism, which promotes Stim proteins binding and activating hexamers of the Orai pore-forming proteins to trigger $\mathrm{Ca}^{2+}$ entry [110]. Stim proteins have two subtypes, Stim1 and Stim2, and there are three subtypes of Orai proteins in mammals, namely Orai1, Orai2 and Orai3 [110]. Orai proteins are four-time transmembrane membrane proteins, and their $\mathrm{N}$-terminus and $\mathrm{C}$-terminus are both in the cytoplasm, and TM1 forms the pore of the ion channel. Stim and Orai proteins widely expressed in various organs and tissues in the human body. Their deficiency or malfunction can lead to alterations in $\mathrm{Ca}^{2+}$ handling and ultimately cause oncogenic transformation [111]. In addition, the TRPC channel has suggested to be a component of SOCE channels [112]. It has reported that Orail is indispensable to TRPC1 function through the dynamic signal complex composed of Stim1- Orai1- TRPC1 [113, 114]. At rest, TRPC1 docked in the trafficking vesicle of the PM. After the storage is depleted, TRPC1 inserts into the PM, which is then gated and activated by Stim1, allowing TRPC1 mediated $\mathrm{Ca}^{2+}$ influx. TRPC1 plays a vital role in the overall function of the SOCE pathway [111]. Altered SOCE activity or the remodelling of SOCE-expression profile have reported in numerous cancers, such as colorectal cancers [115], hepatocellular carcinoma [116], melanoma [117], breast cancer [118], glioblastoma [119] and clear cell renal carcinoma [120]. Until now, tumor cell migration is considered as a $\mathrm{Ca}^{2+}$ dependent process, and calcium channels are major regulators of this process [121]. In non-excitable cells, calcium entry is mainly due to SOCE. Orail and Stim1 are the main calcium channels responsible for $\mathrm{Ca}^{2+}$ entry in lymphocytes [122, 123], and both have been described to be involved in the mediation of actomyosin assembly and the focal adhesions of cancer cell migration [124, 125]. Latour el al have demonstrated that Orail and Stim1 could regulate diffuse large $B$ cell lymphoma (DLBCL) cell motility and dissemination, promoting homing of tumor B cells to extra-nodal sites [126]. Although indepth researches have conducted, little is known about the role of SOCE in MM. Stim1 and Orai1 are the critical components of CRAC channels that highly expressed in $\mathrm{MM}$ bone marrow tissues. And compared with healthy controls, the mRNA levels and protein level of Stim1 and Orai1 were higher in primary MM cells, KM3 and U266 cells [16]. Moreover, U937 and RIMP 8226 MM cell lines also express higher levels of Orai3 [127]. Wang et al. demonstrated that SOCE inhibitors (SKF-96365, DES and 2-APB) affect the biological functions of human MM cell lines, not only inhibited the viability of MM cell lines, caused MM cell cycle arrest, but also induced MM cell apoptosis. Consistently, pretreatment of KM3 and U266 cells with the siRNAs of Stim1 or Orail for $48 \mathrm{~h}$ also reduced cell viability, leading to apoptosis and cell 
cycle arrest in MM cell lines, indicating that SOCE plays a role in MM development [16]. Moreover, clinical data found that Stim1/Orai1 highly expressed in the stage III group than stage II and I group in MM. Progression-free survival (PFS) (15.33 months) of patients in low Stim1 expression was greater than that of PFS (13.34 months) high Stim1 expression group [16]. The above results indicate that Stim1/Orai1 participates in the pathogenesis of $\mathrm{MM}$, but the mechanism by which it works requires further research.

As a potential regulator of SOCE, TRPC1 widely expressed in most tissues, and its dysregulated activity may be a hallmark of many types of cancers, including glioblastoma multiforme [128], breast cancer [129], colon cancer [130], multiple myeloma [131]. Some studies on vitro mechanisms of TRPC1 inducing an increase in intracellular $\mathrm{Ca}^{2+}$ in the MM cell lines, indicating that TRPC1 is related to the development of MM. Knockout of TRPC1 expression showed a reduction in MTI-101(an frist-in-class peptidomimetic that triggers cell death in MM)-induced cell death in U266 and MM.1S MM cell lines [132]. This study suggests that TRPC1 plays an important role in treating MM. However, there is still needed to develop more specific drugs to inhibit or activate TRPC1 function, so that the efficacy of TRPC1 as a potential target for cancer treatment can be verified.

\section{Mitochondrial $\mathrm{Ca}^{2+}$ transporters}

Mitochondria have shown to have a significant contribution to the activity of SOCE, and the ability to chelate $\mathrm{Ca}^{2+}$ locally at the sites of $\mathrm{Ca}^{2+}$ release and entry was supposed to rule SOCE by promoting $\mathrm{Ca}^{2+}$ depletion of the ER and removal from $\mathrm{Ca}^{2+}$ inhibitory channels, respectively [133]. The uptake of mitochondrial $\mathrm{Ca}^{2+}$ must be precisely regulated, because excessive mitochondrial $\mathrm{Ca}^{2+}$ load can cause cell death [134]. Several proteins mediate $\mathrm{Ca}^{2+}$ transport across internal and outernal mitochondrial membranes (IMM, OMM, respectively), including VDAC1 on OMM, and $\mathrm{MCU}$ and $\mathrm{Na}^{+}$dependent mitochondrial $\mathrm{Ca}^{2+}$ efflux transporter (NCLX) on IMM. $\mathrm{Ca}^{2+}$ is transferred to the IMM through OMM. VDAC1 allows $\mathrm{Ca}^{2+}$ to enter MCU, thus promoting $\mathrm{Ca}^{2+}$ transport to the matrix and also from IMM to cytoplasm [11]. This section focuses on VDAC1 and MCU function in the uptake and release of mitochondrial $\mathrm{Ca}^{2+}$ and their effects on MM.

\section{Voltage-dependent anion channel 1 (VDAC1)}

VDAC1 is located on the outer membrane of mitochondria in all eukaryotes and is a pore type protein. VDAC1 is structurally organized into a transmembrane $\beta$-bucket with an $\mathrm{N}$-terminal domain as an $\alpha$ helix [135]. It acts as a voltage-gated channel to control the exchange of small ions and metabolites on the OMM, maintaining many organelle functions $[136,137]$. VDAC1 is the only known $\mathrm{Ca}^{2+}$ transporter on OMM [11, 138], which leading to mitochondrial $\mathrm{Ca}^{2+}$ overload, is a marker of cell apoptosis [139]. Recent studies have shown that apoptosis signal up-regulates VDAC1 in a $\mathrm{Ca}^{2+}$ dependent manner, leading to cell death $[140,141]$. It is now clear that VDAC1 is the main target against cancer. Compared with normal cell lines, the expression of VDAC1 increases in much human cancer cell lines [142]. However, research on the effect of VDAC1 on MM cell apoptosis is still relatively rare. Previous studies have indicated that the expression of CD45 in human myeloma cells is necessary for IL-6-induced proliferation [143]. Liu et al. found that susceptibility to apoptosis by apoptotic stimulis (such as oxidative stress and ER stress) are increased in CD45 ${ }^{+}$ myeloma cell line U266, which highly expressed VDAC1 [17]. Together with the information that expression of VDAC1 in patients with stage III was significantly higher than that in patients with stage I and stage II [144], one could imply that VDAC1 seems to accelerate MM tumor growth, while increase susceptibility to apoptosis, making it a good target candidate for MM therapy.

\section{$\mathrm{Ca}^{2+}$ uniporter (MCU)}

In IMM, the rapid absorption of $\mathrm{Ca}^{2+}$ is mediated by the MCU. MCU can actively shape $\mathrm{Ca}^{2+}$ signaling throughout the cell $[145,146]$. MCU is composed of two transmembrane and $\mathrm{N}$-terminal domains and forms a complex in the IMM with multiple protein regulators, which have an impact on gating [147-149]. It is known that the disregulation of intracellular $\mathrm{Ca}^{2+}$ is among the first hallmarks of apoptosis [150], and some reports indicate that MCU plays an important role in bortezomib-induced apoptosis [151, 152]. Bortezomib is a first-in-class selective PI (proteasome inhibitor), which has been proven to be effective in the treatment of MM. However, most patients eventually develop disease recurrence, and the bortezomib resistance becomes the primary cause of recurrence and incurability of myeloma [153]. Therefore, there is an urgent need to identify the potential mechanism of bortezomib resistance, and find some novel therapeutic targets that can reduce bortezomib resistance in MM. Song et al. found that mitochondrial activity is a determining factor in regulating apoptosis resistance in response to bortezomib, and compared with bortezomib-resistant KMS20 cells, the expression of MCU in bortezomib-sensitive KMS28BM cells were significantly higher under bortezomib stimulation [152]. Furthermore, the cytotoxicity of bortezomib against myeloma cells H929, U266 and MM.1S can be inhibited by mitochondrial $\mathrm{Ca}^{2+}$ uptake inhibitor ruthenium red (a cationic dye that blocks MCU) [151], indicating that changes in MCU 
were related with the resistance of bortezomib. Landowski's team proposed a model in which bortezomib evokes an instantaneous release of $\mathrm{Ca}^{2+}$ stores, leading mitochondrial $\mathrm{Ca}^{2+}$ influx. Mitochondrial $\mathrm{Ca}^{2+}$ sensors associated with uniporters initiate capacitative $\mathrm{Ca}^{2+}$ influx, also called CCI, a phenomenon that IP3R-activated depletion of ER stores is also involved in the regulation of $\mathrm{Ca}^{2+}$ influx from the extracellular environment [154], which is enhanced in bortezomib-treated cells, leading to apoptotic pathways activation [151]. Then, MUC blocker would be protective by blocking mitochondrial loading and $\mathrm{CCI}$ activation and the $\mathrm{Ca}^{2+}$-dependent signal transduction pathways that initiate cell death [155]. Together, $\mathrm{MCU}$ is expected to become a new therapeutic target to reduce MM bortezomib resistance. However, the specific mechanism of MUC participation in resistance still needs intense investigation.

\section{$\mathrm{Ca}^{2+}$-ATPases}

$\mathrm{Ca}^{2+}$-ATPases, which belong to the P-type pump superfamily, are involved in maintaining low cytoplasmic $\mathrm{Ca}^{2+}$ levels at rest and initiating organelle stores [156]. They quickly pump cytosolic $\mathrm{Ca}^{2+}$ ions back to intracellular organelles, such as ER, or to squeeze $\mathrm{Ca}^{2+}$ ions into extracellular space [10]. According to their subcellular location, $\mathrm{Ca}^{2+}$-ATPases can be divided into three subtypes: plasma membrane (plasma membrane $\mathrm{Ca}^{2+}$ -ATPase or PMCA), endoplasmic reticulum (Sarco/ endoplasmic reticulum $\mathrm{Ca}^{2+}$-ATPase or SERCA) and Golgi apparatus / Golgi-derived vesicles (secretory pathway $\mathrm{Ca}^{2+}$-ATPase or SPCA) [157] (Fig. 1). Among them, SERCA is the most distinctive one, which is responsible for replenishing ER $\mathrm{Ca}^{2+}$ storage and maintaining correct folding of proteins. SERCA imbalance leads to decreased or overloaded $\mathrm{Ca}^{2+}$ storage in the ER lumen, increased ER stress, chaperones protein imbalance and lipid synthesis $[10,158]$. Their expression levels and tissue distribution in the body are different [159]. Mutations and changes in SERCA subtypes expression levels have confirmed in a variety of cancers, such as colon cancer, gastric cancer, lung cancer, myeloid leukemia, and choroid plexus tumors [160]. Roti and his colleagues showed that SERCA inhibition preferentially damages the maturation of leukemia-related mutant $\mathrm{NOTCH}$ receptors, leading to G0/G1 arrest [161]. PMCA is a calcium pump that relies on ATP to drive $\mathrm{Ca}^{2+}$ out of the cell. When PMCA expression is abnormal, it will cause the disorder of $\mathrm{Ca}^{2+}$ balance in the cell. Studies have found that plasma membrane PMCA is abnormally expressed in various malignant tumors, including breast cancer [162], colon cancer [163], pancreatic cancer [164], and so on. PMCA proved to be a part of the $\mathrm{Ca}^{2+}$ exclusion system, but the role of each subtype of PMCA has not studied extensively.
The main reason is the lack of specific inhibitors of each subtype of PMCA. The third newly discovered subtype is SPCA, a freshly discovered subtype, include calcium pumps located in the Golgi compartments and postGolgi vesicles [156]. Changed expression of SPCA subtypes occurs in various types of cancer including breast, prostate and colon cancer [165]. The results of the above studies have shown that $\mathrm{Ca}^{2+}$-ATPase is used to promote the escape of specific cancer cells from normal cellular control and accelerate tumorigenesis. Although clear evidence linking $\mathrm{Ca}^{2+}$-ATPases to several malignancies, rare reports about the study of $\mathrm{Ca}^{2+}$-ATPase in MM. Further study the role of $\mathrm{Ca}^{2+}$-ATPase in MM will contribute to understanding the complex intracellular $\mathrm{Ca}^{2+}$ signaling network in MM.

\section{Conclusion}

Calcium channels and transporters play a vital role in the regulation of $\mathrm{Ca}^{2+}$ transport and participate in multiple physiological and pathological processes, including the progression of cancer. Although various studies have reported the role of ion transporters in MM, the mechanism by which $\mathrm{Ca}^{2+}$ imbalance caused by defective ion transporter function leads to the occurrence of MM remains unclear. Therefore, it is particularly significant to elucidate the aetiology and pathogenesis of $\mathrm{MM}$ and explore new tumor markers for early diagnosis and treatment. In this review, we concerned about the effects of various calcium channels and transporters abnormalities on the development of MM, including many plasma membrane $\mathrm{Ca}^{2+}$ channels, SOCE, Mitochondrial $\mathrm{Ca}^{2+}$ transporters and $\mathrm{Ca}^{2+}$-ATPases. This review aims to stimulate people's interest in and to provide a basic, systematic overview of the research in this field, thereby providing new directions for the prognosis and treatment of MM by targeting $\mathrm{Ca}^{2+}$ channels or transporters.

\footnotetext{
Abbreviations

$\mathrm{Ca}_{0}{ }^{2+}$ : Extracellular calcium concentrations; $\mathrm{Ca}_{\mathrm{i}}{ }^{2+}$ : Intracellular calcium concentrations; CaSR: Calcium sensitive receptor; CCLE: Cancer cell line encyclopedia; CCl: Capacitative Ca ${ }^{2+}$ influx; CLL: Chronic lymphocytic leukaemia; CT: Calcitonin; CTR: Calcitonin receptor; DLBCL: Diffuse large B cell lymphoma; ECD: Extracellular domain; ER/SR: Endoplasmic/sarcoplasmic reticulum; GA: Golgi apparatus; GPCRs: G protein-coupled receptors; IMM: Internal mitochondrial membranes; IP3R: Inositol 1,4,5-triphate receptor; IGF-1: Interleukin-6 (IL-6), insulin-like growth factor-1; MAPK: Mitogen-activated protein kinase; MBD: Myeloma bone disease; MCP-1: Monocyte chemoattractant protein 1; MCU: Mitochondrial $\mathrm{Ca}^{2+}$ uniporter; Mit: Mitochondrial; MM: Multiple myeloma; MMP2: Metalloproteinase 2; $\mathrm{NCLX}: \mathrm{Na}^{+}$dependent mitochondrial $\mathrm{Ca}^{2+}$ efflux transporter; OCs: Osteoclasts; OMM: Outernal mitochondrial membranes; IMM: Internal mitochondrial membranes; PFS: Progression-free survival; PM: Plasma membrane; PMCA: Plasma membrane Ca ${ }^{2+}$-ATPase; PTH: Parathyroid hormone; PTH-R1: Parathyroid hormone-related protein Receptor; PTHrP: Parathyroid hormone-related protein; RA NKL: Nuclear factor-k B ligand; RyR: Ryanodine receptor; ROS: Reactive oxygen species; SOCE: Store-operated $\mathrm{Ca}^{2+}$ entry; SERCA: Sarco/endoplasmic reticulum Ca ${ }^{2+}$-ATPase; STAT3: Activator of transcription 3; Stim 1: Stromal-interaction molecule1; SPCA: Secretory
} 
pathway $\mathrm{Ca}^{2+}$-ATPase; TTM:Transmembrane domain; TRP:Transient receptor potential channel; TRPV: Transient receptor potential channel subfamily V; UPR: Unfolded protein response; VDAC1: Voltage-dependent anion channel 1.

\section{Acknowledgements}

Not applicable.

\section{Authors' contributions}

T.T.L conceived and wrote the manuscript. J.M.C and Z.Y.Z revised the manuscript. All authors read and approved the final manuscript.

\section{Funding}

This work was supported by grants from the National Natural Science Foundation of China (Nos. 81400160 and 82070218), the Natural Science Foundation of Fujian Province (No. 2017J01 185), and Clinical research project of Wu Jieping Medical Foundation (Nos. 320.6750.19094-41 and 320.6750.19094-58).

\section{Declarations}

\section{Competing interests}

The authors have declared that no competing interest exists.

\section{Author details}

'Department of Hematology, The First Affiliated Hospital of Fujian Medical University, 20 Chazhong Road, Fuzhou, Fujian 350005, People's Republic of China. ${ }^{2}$ Fujian Key Laboratory of Laboratory Medicine, Fuzhou, People's Republic of China.

Received: 3 June 2021 Accepted: 28 August 2021

Published online: 27 September 2021

\section{References}

1. Mimura N, Hideshima T, Anderson KC. Novel therapeutic strategies for multiple myeloma. Exp Hematol. 2015;43:732-41.

2. Kumar SK, Rajkumar V, Kyle RA, van Duin M, Sonneveld P, Mateos MV, et al. Multiple myeloma. Nat Rev Disease Primers. 2017;3:17046.

3. Rasch S, Lund T, Asmussen JT, Lerberg Nielsen A, Faebo Larsen R, Østerheden Andersen $\mathrm{M}$, et al. Multiple myeloma associated bone disease. Cancers. 2020;12:2113.

4. Palumbo A, Anderson K. Multiple myeloma. N Engl J Med. 2011;364:1046-60.

5. Stewart AF. Clinical practice. Hypercalcemia associated with cancer. N Engl J Med. 2005;352:373-9.

6. Zagouri F, Kastritis E, Zomas A, Terpos E, Katodritou E, Symeonidis A, et al. Hypercalcemia remains an adverse prognostic factor for newly diagnosed multiple myeloma patients in the era of novel antimyeloma therapies. Eur J Haematol. 2017;99:409-14.

7. Oyajobi BO. Multiple myeloma/hypercalcemia. Arthritis Res Therapy. 2007;9(Suppl 1):S4.

8. Tuttle KR, Kunau RT, Loveridge N, Mundy GR. Altered renal calcium handling in hypercalcemia of malignancy. J Am Soc Nephrol. 1991;2:191-9.

9. Silver IA, Murrills RJ, Etherington DJ. Microelectrode studies on the acid microenvironment beneath adherent macrophages and osteoclasts. Exp Cell Res. 1988;175:266-76.

10. Cui C, Merritt R, Fu L, Pan Z. Targeting calcium signaling in cancer therapy. Acta pharmaceutica Sinica B. 2017;7:3-17.

11. Shoshan-Barmatz V, De S. Mitochondrial VDAC, the $\mathrm{Na}(+) / \mathrm{Ca}(2+)$ exchanger, and the $\mathrm{Ca}(2+)$ uniporter in $\mathrm{Ca}(2+)$ dynamics and signaling. Adv Exp Med Biol. 2017;981:323-47.

12. Hanahan D, Weinberg RA. The hallmarks of cancer. Cell. 2000;100:57-70.

13. Bai H, Zhu H, Yan Q, Shen X, Lu X, Wang J, et al. TRPV2-induced Ca(2+)calcineurin-NFAT signaling regulates differentiation of osteoclast in multiple myeloma. Cell Commun Signal. 2018;16:68.

14. Cao B, Dai X, Wang W. Knockdown of TRPV4 suppresses osteoclast differentiation and osteoporosis by inhibiting autophagy through $\mathrm{Ca}(2+)$ -calcineurin-NFATc1 pathway. J Cell Physiol. 2019;234:6831-41.
15. Farrell AW, Gadeock S, Pupovac A, Wang B, Jalilian I, Ranson M, et al. P2X7 receptor activation induces cell death and CD23 shedding in human RPMI 8226 multiple myeloma cells. Biochem Biophys Acta. 2010;1800:1173-82.

16. Wang W, Ren Y, Wang L, Zhao W, Dong X, Pan J, et al. Orai1 and stim1 mediate the majority of store-operated calcium entry in multiple myeloma and have strong implications for adverse prognosis. Cell Physiol Biochem: Int J Exp Cell Physiol Biochem Pharmacol. 2018;48:2273-85.

17. Liu S, Ishikawa H, Tsuyama N, Li FJ, Abroun S, Otsuyama Kl, et al. Increased susceptibility to apoptosis in CD45(+) myeloma cells accompanied by the increased expression of VDAC1. Oncogene. 2006;25:419-29.

18. Wu LJ, Sweet TB, Clapham DE. International union of basic and clinical pharmacology. LXXVI. Current progress in the mammalian TRP ion channel family. Pharmacol Rev. 2010;62:381-404.

19. Clapham DE. SnapShot: mammalian TRP channels. Cell. 2007;129:220.

20. Minke B. TRP channels and Ca2+ signaling. Cell Calcium. 2006:40:261-75.

21. Taberner FJ, Devesa I, Ferrer-Montiel A. Calcium entry through thermosensory channels. Adv Exp Med Biol. 2016;898:265-304.

22. Eda H, Santo L, David Roodman G, Raje N. Bone disease in multiple myeloma. Cancer Treat Res. 2016;169:251-70.

23. Roodman GD. Targeting the bone microenvironment in multiple myeloma. J Bone Miner Metab. 2010;28:244-50.

24. Fabris S, Todoerti K, Mosca L, Agnelli L, Intini D, Lionetti M, et al. Molecular and transcriptional characterization of the novel 17p11.2p12 amplicon in multiple myeloma. Genes Chromosomes Cancer. 2007:46:1109-18.

25. Krishnamoorthy M, Wasim L, Buhari FHM, Zhao T, Mahtani T, Ho J, et al. The channel-kinase TRPM7 regulates antigen gathering and internalization in B cells. Science signaling. 2018;11:eaah6692.

26. Launay P, Cheng H, Srivatsan S, Penner R, Fleig A, Kinet JP. TRPM4 regulates calcium oscillations after T cell activation. Science (New York, NY). 2004;306:1374-7.

27. van Goor MK, de Jager L, Cheng Y, van der Wijst J. High-resolution structures of transient receptor potential vanilloid channels: Unveiling a functionally diverse group of ion channels. Protein Sci: Publ Protein Soc. 2020;29:1569-80.

28. Clapham DE. TRP channels as cellular sensors. Nature. 2003;426:517-24.

29. Guarino BD, Paruchuri S, Thodeti CK. The role of TRPV4 channels in ocular function and pathologies. Exp Eye Res. 2020;201:108257.

30. Venkatachalam K, Montell C. TRP channels. Annu Rev Biochem. 2007;76:387-417.

31. van Goor MKC, Hoenderop JGJ, van der Wijst J. TRP channels in calcium homeostasis: from hormonal control to structure-function relationship of TRPV5 and TRPV6. Biochim Biophys Acta. 2017;1864:883-93.

32. Fleig A, Penner R. The TRPM ion channel subfamily: molecular, biophysical and functional features. Trends Pharmacol Sci. 2004;25:633-9.

33. Huang Y, Fliegert R, Guse AH, Lü W, Du J. A structural overview of the ion channels of the TRPM family. Cell Calcium. 2020;85:102111.

34. Launay P, Fleig A, Perraud AL, Scharenberg AM, Penner R, Kinet JP. TRPM4 is a Ca2+-activated nonselective cation channel mediating cell membrane depolarization. Cell. 2002;109:397-407.

35. Hofmann T, Chubanov V, Gudermann T, Montell C. TRPM5 is a voltagemodulated and $\mathrm{Ca}(2+)$-activated monovalent selective cation channel. Current Biol: CB. 2003;13:1153-8.

36. Winter Z, Buhala A, Ötvös F, Jósvay K, Vizler C, Dombi G, et al. Functionally important amino acid residues in the transient receptor potential vanilloid 1 (TRPV1) ion channel-an overview of the current mutational data. Mol Pain. 2013;9:30.

37. Yang F, Zheng J. Understand spiciness: mechanism of TRPV1 channel activation by capsaicin. Protein Cell. 2017:8:169-77.

38. Caterina MJ, Schumacher MA, Tominaga M, Rosen TA, Levine JD, Julius D. The capsaicin receptor: a heat-activated ion channel in the pain pathway. Nature. 1997;389:816-24.

39. Marrone MC, Morabito A, Giustizieri M, Chiurchiù V, Leuti A, Mattioli $M$, et al. TRPV1 channels are critical brain inflammation detectors and neuropathic pain biomarkers in mice. Nat Commun. 2017;8:15292.

40. Riera CE, Huising MO, Follett P, Leblanc M, Halloran J, Van Andel R, et al. TRPV 1 pain receptors regulate longevity and metabolism by neuropeptide signaling. Cell. 2014;157:1023-36. 
41. Lozano C, Córdova C, Marchant I, Zúñiga R, Ochova P, Ramírez-Barrantes $R$, et al. Intracellular aggregated TRPV1 is associated with lower survival in breast cancer patients. Breast Cancer (Dove Medical Press). 2018;10:161-8.

42. Sanchez MG, Sanchez AM, Collado B, Malagarie-Cazenave S, Olea N, Carmena MJ, et al. Expression of the transient receptor potential vanilloid 1 (TRPV1) in LNCaP and PC-3 prostate cancer cells and in human prostate tissue. Eur J Pharmacol. 2005;515:20-7.

43. Amantini C, Ballarini P, Caprodossi S, Nabissi M, Morelli MB, Lucciarini R, et al. Triggering of transient receptor potential vanilloid type 1 (TRPV1) by capsaicin induces Fas/CD95-mediated apoptosis of urothelial cancer cells in an ATM-dependent manner. Carcinogenesis. 2009;30:1320-9.

44. Amantini C, Mosca M, Nabissi M, Lucciarini R, Caprodossi S, Arcella A, et al. Capsaicin-induced apoptosis of glioma cells is mediated by TRPV1 vanilloid receptor and requires p38 MAPK activation. J Neurochem. 2007;102:977-90.

45. Büsselberg D, Florea AM. Targeting intracellular calcium signaling $([\mathrm{Ca}(2+)](\mathrm{i}))$ to overcome acquired multidrug resistance of cancer cells: a mini-overview. Cancers. 2017;9:48.

46. Obeng EA, Carlson LM, Gutman DM, Harrington WJ Jr, Lee KP, Boise LH. Proteasome inhibitors induce a terminal unfolded protein response in multiple myeloma cells. Blood. 2006;107:4907-16.

47. Beider K, Rosenberg E, Dimenshtein-Voevoda V, Sirovsky Y, Vladimirsky $J$, Magen $\mathrm{H}$, et al. Blocking of Transient Receptor Potential Vanilloid 1 (TRPV1) promotes terminal mitophagy in multiple myeloma, disturbing calcium homeostasis and targeting ubiquitin pathway and bortezomibinduced unfolded protein response. J Hematol Oncol. 2020;13:158.

48. Brookes PS, Yoon Y, Robotham JL, Anders MW, Sheu SS. Calcium, ATP, and ROS: a mitochondrial love-hate triangle. Am J Physiol Cell Physiol. 2004;287:C817-33.

49. Everaerts W, Gevaert T, Nilius B, De Ridder D. On the origin of bladder sensing: $\operatorname{Tr}(i)$ ps in urology. Neurourol Urodyn. 2008;27:264-73.

50. Santoni G, Farfariello V, Liberati S, Morelli MB, Nabissi M, Santoni M, et al. The role of transient receptor potential vanilloid type-2 ion channels in innate and adaptive immune responses. Front Immunol. 2013:4:34.

51. Park KS, Pang B, Park SJ, Lee YG, Bae JY, Park S, et al. Identification and functional characterization of ion channels in CD34(+) hematopoietic stem cells from human peripheral blood. Mol Cells. 2011;32:181-8.

52. Liu G, Xie C, Sun F, Xu X, Yang Y, Zhang T, et al. Clinical significance of transient receptor potential vanilloid 2 expression in human hepatocelIular carcinoma. Cancer Genet Cytogenet. 2010;197:54-9.

53. Zhou K, Zhang SS, Yan Y, Zhao S. Overexpression of transient receptor potential vanilloid 2 is associated with poor prognosis in patients with esophageal squamous cell carcinoma. Med Oncol (Northwood, London, England). 2014;31:17.

54. Monet M, Lehen'kyi V, Gackiere F, Firlej V, Vandenberghe M, Roudbaraki $\mathrm{M}$, et al. Role of cationic channel TRPV2 in promoting prostate cancer migration and progression to androgen resistance. Can Res. 2010;70:1225-35.

55. Zhang W, Chu X, Tong Q, Cheung JY, Conrad K, Masker K, et al. A novel TRPM2 isoform inhibits calcium influx and susceptibility to cell death. J Biol Chem. 2003;278:16222-9.

56. Narayan G, Bourdon V, Chaganti S, Arias-Pulido H, Nandula SV, Rao PH, et al. Gene dosage alterations revealed by CDNA microarray analysis in cervical cancer: identification of candidate amplified and overexpressed genes. Genes Chromosom Cancer. 2007;46:373-84.

57. Yamaguchi T, Yamauchi M, Sugimoto T, Chauhan D, Anderson KC, Brown EM, et al. The extracellular calcium Ca2+o-sensing receptor is expressed in myeloma cells and modulates cell proliferation. Biochem Biophys Res Commun. 2002;299:532-8.

58. White JP, Cibelli M, Urban L, Nilius B, McGeown JG, Nagy I. TRPV4: molecular conductor of a diverse orchestra. Physiol Rev. 2016;96:911-73

59. Li P, Bian X, Liu C, Wang S, Guo M, Tao Y, et al. STIM1 and TRPV4 regulate fluid flow-induced calcium oscillation at early and late stages of osteoclast differentiation. Cell Calcium. 2018;71:45-52.

60. Masuyama R, Mizuno A, Komori H, Kajiya H, Uekawa A, Kitaura H, et al. Calcium/calmodulin-signaling supports TRPV4 activation in osteoclasts and regulates bone mass. J Bone Miner Res: Off J Am Soc Bone Miner Res. 2012;27:1708-21.
61. Shapiro IM, Layfield R, Lotz M, Settembre C, Whitehouse C. Boning up on autophagy: the role of autophagy in skeletal biology. Autophagy. 2014;10:7-19.

62. Duan J, Li Z, Li J, Hulse RE, Santa-Cruz A, Valinsky WC, et al. Structure of the mammalian TRPM7, a magnesium channel required during embryonic development. Proc Natl Acad Sci USA. 2018;115:E8201-10.

63. Yee NS. Role of TRPM7 in cancer: potential as molecular biomarker and therapeutic target. Pharmaceuticals (Basel, Switzerland). 2017;10:39.

64. Liu L, Wu N, Wang Y, Zhang X, Xia B, Tang J, et al. TRPM7 promotes the epithelial-mesenchymal transition in ovarian cancer through the calcium-related PI3K / AKT oncogenic signaling. J Exp Clin Cancer Re: CR. 2019;38:106.

65. Nadler MJ, Hermosura MC, Inabe K, Perraud AL, Zhu Q, Stokes AJ, et al. LTRPC7 is a Mg.ATP-regulated divalent cation channel required for cell viability. Nature. 2001;411:590-5.

66. Weinstock M, Ghobrial IM. Extramedullary multiple myeloma. Leukemia Lymphoma. 2013;54:1135-41.

67. de Haart SJ, Willems SM, Mutis T, Koudijs MJ, van Blokland MT, Lokhorst HM, et al. Comparison of intramedullary myeloma and corresponding extramedullary soft tissue plasmacytomas using genetic mutational panel analyses. Blood Cancer J. 2016;6:e426.

68. Samart P, Luanpitpong S, Rojanasakul Y, Issaragrisil S. O-GIcNAcylation homeostasis controlled by calcium influx channels regulates multiple myeloma dissemination. J Exp Clin Cancer Res: CR. 2021;40:100.

69. Ghobrial IM. Myeloma as a model for the process of metastasis: implications for therapy. Blood. 2012;120:20-30.

70. Bhutani M, Foureau DM, Atrash S, Voorhees PM, Usmani SZ. Extramedullary multiple myeloma. Leukemia. 2020;34:1-20.

71. Fredriksson R, Lagerström MC, Lundin LG, Schiöth HB. The G-proteincoupled receptors in the human genome form five main families. Phylogenetic analysis, paralogon groups, and fingerprints. Mol Pharmacol. 2003;63:1256-72.

72. Pin JP, Bettler B. Organization and functions of $\mathrm{mGlu}$ and $\mathrm{GABA}(\mathrm{B})$ receptor complexes. Nature. 2016;540:60-8.

73. Gurevich WV, Gurevich EV. GPCR signaling regulation: the role of GRKs and arrestins. Front Pharmacol. 2019;10:125.

74. Brown EM, Gamba G, Riccardi D, Lombardi M, Butters R, Kifor O, et al. Cloning and characterization of an extracellular $\mathrm{Ca}(2+)$-sensing receptor from bovine parathyroid. Nature. 1993;366:575-80.

75. Zhang C, Zhang T, Zou J, Miller CL, Gorkhali R, Yang JY, et al. Structural basis for regulation of human calcium-sensing receptor by magnesium ions and an unexpected tryptophan derivative co-agonist. Sci Adv. 2016;2:e1600241.

76. Ranieri $\mathrm{M}$. Renal $\mathrm{Ca}(2+)$ and water handling in response to calcium sensing receptor signaling: physiopathological aspects and role of CaSR-regulated microRNAs. Int J Mol Sci. 2019;20:5341.

77. Whitaker M, Larman MG. Calcium and mitosis. Semin Cell Dev Biol. 2001;12:53-8.

78. Yamaguchi T, Chattopadhyay N, Kifor O, Butters RR Jr, Sugimoto T, Brown EM. Mouse osteoblastic cell line (MC3T3-E1) expresses extracellular calcium (Ca2+o)-sensing receptor and its agonists stimulate chemotaxis and proliferation of MC3T3-E1 cells. J Bone Miner Res: Off J Am Soc Bone Miner Res. 1998:13:1530-8.

79. Quarles LD, Hartle JE 2nd, Middleton JP, Zhang J, Arthur JM, Raymond JR. Aluminum-induced DNA synthesis in osteoblasts: mediation by a G-protein coupled cation sensing mechanism. J Cell Biochem. 1994:56:106-17.

80. Yamaguchi T, Chattopadhyay N, Kifor O, Sanders JL, Brown EM. Activation of p42/44 and p38 mitogen-activated protein kinases by extracellular calcium-sensing receptor agonists induces mitogenic responses in the mouse osteoblastic MC3T3-E1 cell line. Biochem Biophys Res Commun. 2000;279:363-8.

81. House MG, Kohlmeier L, Chattopadhyay N, Kifor O, Yamaguchi T, Leboff MS, et al. Expression of an extracellular calcium-sensing receptor in human and mouse bone marrow cells. J Bone Miner Res: Off J Am Soc Bone Miner Res. 1997;12:1959-70.

82. Mitsiades CS, Mitsiades N, Poulaki V, Schlossman R, Akiyama M, Chauhan $D$, et al. Activation of NF-kappaB and upregulation of intracellular anti-apoptotic proteins via the IGF-1/Akt signaling in human multiple myeloma cells: therapeutic implications. Oncogene. 2002;21:5673-83. 
83. Podar K, Tai YT, Davies FE, Lentzsch S, Sattler M, Hideshima T, et al. Vascular endothelial growth factor triggers signaling cascades mediating multiple myeloma cell growth and migration. Blood. 2001;98:428-35.

84. Lin HY, Harris TL, Flannery MS, Aruffo A, Kaji EH, Gorn A, et al. Expression cloning of an adenylate cyclase-coupled calcitonin receptor. Science (New York, NY). 1991;254:1022-4.

85. Silvestris F, Cafforio P, De Matteo M, Quatraro C, Dammacco F. Expression and function of the calcitonin receptor by myeloma cells in their osteoclast-like activity in vitro. Leuk Res. 2008;32:611-23.

86. Dal Maso E, Glukhova A, Zhu Y, Garcia-Nafria J, Tate CG, Atanasio S, et al. The molecular control of calcitonin receptor signaling. ACS Pharmacol Transl Sci. 2019;2:31-51.

87. Shyu JF, Zhang Z, Hernandez-Lagunas L, Camerino C, Chen Y, Inoue D, et al. Protein kinase $C$ antagonizes pertussis-toxin-sensitive coupling of the calcitonin receptor to adenylyl cyclase. Eur J Biochem. 1999;262:95-101.

88. Ikegame M, Rakopoulos M, Zhou H, Houssami S, Martin TJ, Moseley JM, et al. Calcitonin receptor isoforms in mouse and rat osteoclasts. J Bone Miner Res: Off J Am Soc Bone Miner Res. 1995;10:59-65.

89. Bowler WB, Gallagher JA, Bilbe G. G-protein coupled receptors in bone. Front Biosci. 1998;3:d769-80.

90. Kremer R, Li J, Camirand A, Karaplis AC. Parathyroid hormone related protein (PTHrP) in tumor progression. Adv Exp Med Biol. 2011;720:145-60.

91. Fujita T, Meguro T, Fukuyama R, Nakamuta H, Koida M. New signaling pathway for parathyroid hormone and cyclic AMP action on extracellular-regulated kinase and cell proliferation in bone cells. Checkpoint of modulation by cyclic AMP. J Biol Chem. 2002;277:22191-200.

92. Cafforio P, Savonarola A, Stucci S, De Matteo M, Tucci M, Brunetti AE, et al. PTHrP produced by myeloma plasma cells regulates their survival and pro-osteoclast activity for bone disease progression. J Bone Miner Res: Off J Am Soc Bone Miner Res. 2014;29:55-66.

93. Pacheco PAF, Dantas LP, Ferreira LGB, Faria RX. Purinergic receptors and neglected tropical diseases: why ignore purinergic signaling in the search for new molecular targets? J Bioenerg Biomembr. 2018;50:307-13.

94. Pawson AJ, Sharman JL, Benson HE, Faccenda E, Alexander SP, Buneman OP, et al. The IUPHAR/BPS Guide to PHARMACOLOGY: an expert-driven knowledgebase of drug targets and their ligands. Nucleic Acids Res. 2014;42:D1098-106

95. Qu Y, Dubyak GR. P2X7 receptors regulate multiple types of membrane trafficking responses and non-classical secretion pathways. Purinergic Signal. 2009;5:163-73.

96. Adinolfi E, Pizzirani C, Idzko M, Panther E, Norgauer J, Di Virgilio F, et al. P2X(7) receptor: death or life? Purinergic Signal. 2005;1:219-27.

97. Adinolfi E, Melchiorri L, Falzoni S, Chiozzi P, Morelli A, Tieghi A, et al. $\mathrm{P} 2 \mathrm{X7}$ receptor expression in evolutive and indolent forms of chronic $B$ lymphocytic leukemia. Blood. 2002;99:706-8.

98. Wiley JS, Dao-Ung LP, Gu BJ, Sluyter R, Shemon AN, Li C, et al. A lossof-function polymorphic mutation in the cytolytic $\mathrm{P} 2 \mathrm{X} 7$ receptor gene and chronic lymphocytic leukaemia: a molecular study. Lancet (London, England). 2002;359:1114-9.

99. Gu B, Bendall $L$, Wiley JS. Adenosine triphosphate-induced shedding of CD23 and L-selectin (CD62L) from lymphocytes is mediated by the same receptor but different metalloproteases. Blood. 1998;92:946-51.

100. Acharya M, Borland G, Edkins AL, Maclellan LM, Matheson J, Ozanne BW, et al. CD23/FceRII: molecular multi-tasking. Clin Exp Immunol. 2010;162:12-23.

101. Pupovac A, Geraghty NJ, Watson D, Sluyter R. Activation of the P2X7 receptor induces the rapid shedding of CD23 from human and murine B cells. Immunol Cell Biol. 2015;93:77-85.

102. Sarfati M, Bron D, Lagneaux L, Fonteyn C, Frost H, Delespesse G. Elevation of IgE-binding factors in serum of patients with $B$ cell-derived chronic lymphocytic leukemia. Blood. 1988;71:94-8.

103. Sarfati M, Chevret S, Chastang C, Biron G, Stryckmans P, Delespesse G, et al. Prognostic importance of serum soluble CD23 level in chronic lymphocytic leukemia. Blood. 1996;88:4259-64.

104. Barna G, Reiniger L, Tátrai P, Kopper L, Matolcsy A. The cut-off levels of CD23 expression in the differential diagnosis of MCL and CLL. Hematol Oncol. 2008;26:167-70.
105. Schlette E, Fu K, Medeiros LJ. CD23 expression in mantle cell lymphoma: clinicopathologic features of 18 cases. Am J Clin Pathol. 2003;120:760-6.

106. Walters M, Olteanu H, Van Tuinen P, Kroft SH. CD23 expression in plasma cell myeloma is specific for abnormalities of chromosome 11, and is associated with primary plasma cell leukaemia in this cytogenetic sub-group. Br J Haematol. 2010;149:292-3.

107. Parekh AB, Putney JW Jr. Store-operated calcium channels. Physiol Rev. 2005;85:757-810.

108. Pan Z, Brotto M, Ma J. Store-operated Ca2+ entry in muscle physiology and diseases. BMB Rep. 2014;47:69-79.

109. Zhou Y, Cai X, Nwokonko RM, Loktionova NA, Wang Y, Gill DL. The STIM-Orai coupling interface and gating of the Orai1 channel. Cell Calcium. 2017;63:8-13.

110. Lewis RS. Store-operated calcium channels: from function to structure and back again. Cold Spring Harbor Perspect Biol. 2020;12:a035055.

111. Pierro C, Sneyers F, Bultynck G, Roderick HL. ER Ca(2+) release and store-operated $\mathrm{Ca}(2+)$ entry - partners in crime or independent actors in oncogenic transformation? Cell Calcium. 2019;82:102061.

112. Lopez JJ, Jardin I, Sanchez-Collado J, Salido GM, Smani T, Rosado JA. TRPC channels in the SOCE scenario. Cells. 2020;9:126.

113. Ambudkar IS, de Souza LB, Ong HL. TRPC1, Orai1, and STIM1 in SOCE: friends in tight spaces. Cell Calcium. 2017;63:33-9.

114. Cheng KT, Ong HL, Liu X, Ambudkar IS. Contribution of TRPC1 and Orai1 to $\mathrm{Ca}(2+)$ entry activated by store depletion. Adv Exp Med Biol. 2011;704:435-49.

115. Zuccolo E, Laforenza U, Ferulli F, Pellavio G, Scarpellino G, Tanzi M, et al. Stim and Orai mediate constitutive $\mathrm{Ca}(2+)$ entry and control endoplasmic reticulum $\mathrm{Ca}(2+)$ refilling in primary cultures of colorectal carcinoma cells. Oncotarget. 2018;9:31098-119.

116. Yang $N$, Tang Y, Wang F, Zhang H, Xu D, Shen Y, et al. Blockade of store-operated $\mathrm{Ca}(2+)$ entry inhibits hepatocarcinoma cell migration and invasion by regulating focal adhesion turnover. Cancer Lett. 2013:330:163-9.

117. Stanisz H, Saul S, Müller CS, Kappl R, Niemeyer BA, Vogt T, et al. Inverse regulation of melanoma growth and migration by Orai1/STIM2dependent calcium entry. Pigment Cell Melanoma Res. 2014;27:442-53.

118. McAndrew D, Grice DM, Peters AA, Davis FM, Stewart T, Rice M, et al. ORAl1-mediated calcium influx in lactation and in breast cancer. Mol Cancer Ther. 2011;10:448-60.

119. Motiani RK, Hyzinski-García MC, Zhang X, Henkel MM, Abdullaev IF Kuo YH, et al. STIM1 and Orai1 mediate CRAC channel activity and are essential for human glioblastoma invasion. Pflugers Arch: Eur J Physiol. 2013;465:1249-60.

120. Kim JH, Lkhagvadorj S, Lee MR, Hwang KH, Chung HC, Jung JH, et al. Orai1 and STIM1 are critical for cell migration and proliferation of clear cell renal cell carcinoma. Biochem Biophys Res Commun. 2014:448:76-82.

121. lamshanova O, Fiorio Pla A, Prevarskaya N. Molecular mechanisms of tumour invasion: regulation by calcium signals. J Physiol. 2017;595:3063-75.

122. Feske S, Wulff H, Skolnik EY. Ion channels in innate and adaptive immunity. Annu Rev Immunol. 2015;33:291-353.

123. Yeromin AV, Zhang SL, Jiang W, Yu Y, Safrina O, Cahalan MD. Molecular identification of the CRAC channel by altered ion selectivity in a mutant of Orai. Nature. 2006;443:226-9.

124. Chen YF, Chiu WT, Chen YT, Lin PY, Huang HJ, Chou CY, et al. Calcium store sensor stromal-interaction molecule 1-dependent signaling plays an important role in cervical cancer growth, migration, and angiogenesis. Proc Natl Acad Sci USA. 2011;108:15225-30.

125. Chen YT, Chen YF, Chiu WT, Wang YK, Chang HC, Shen MR. The ER Ca2+ sensor STIM1 regulates actomyosin contractility of migratory cells. J Cell Sci. 2013;126:1260-7.

126. Latour S, Mahouche I, Cherrier F, Azzi-Martin L, Velasco V, Soubeyran P, et al. Calcium independent effect of orai1 and STIM1 in non-Hodgkin B cell lymphoma dissemination. Cancers. 2018;10:402.

127. Yanamandra N, Buzzeo RW, Gabriel M, Hazlehurst LA, Mari Y, Beaupre DM, et al. Tipifarnib-induced apoptosis in acute myeloid leukemia and multiple myeloma cells depends on Ca2 + influx through plasma membrane Ca2+ channels. J Pharmacol Exp Ther. 2011;337:636-43. 
128. Lepannetier S, Zanou N, Yerna X, Emeriau N, Dufour I, Masquelier J, et al. Sphingosine-1-phosphate-activated TRPC1 channel controls chemotaxis of glioblastoma cells. Cell Calcium. 2016;60:373-83.

129. Faouzi M, Hague F, Geerts D, Ay AS, Potier-Cartereau M, Ahidouch A, et al. Functional cooperation between KCa3.1 and TRPC1 channels in human breast cancer: role in cell proliferation and patient prognosis. Oncotarget. 2016;7:36419-35.

130. Guéguinou M, Harnois T, Crottes D, Uguen A, Deliot N, Gambade A, et al. SK3/TRPC1/Orai1 complex regulates SOCE-dependent colon cancer cell migration: a novel opportunity to modulate anti-EGFR mAb action by the alkyl-lipid Ohmline. Oncotarget. 2016;7:36168-84.

131. Elzamzamy OM, Penner R, Hazlehurst LA. The role of TRPC1 in modulating cancer progression. Cells. 2020;9:338.

132. Emmons MF, Anreddy N, Cuevas J, Steinberger K, Yang S, McLaughlin M, et al. MTI-101 treatment inducing activation of Stim1 and TRPC1 expression is a determinant of response in multiple myeloma. Sci Rep. 2017;7:2685.

133. Demaurex N, Poburko D, Frieden M. Regulation of plasma membrane calcium fluxes by mitochondria. Biochem Biophys Acta. 2009:1787:1383-94.

134. Duchen MR, Verkhratsky A, Muallem S. Mitochondria and calcium in health and disease. Cell Calcium. 2008:44:1-5.

135. Colombini M. VDAC structure, selectivity, and dynamics. Biochem Biophys Acta. 2012;1818:1457-65.

136. Magrì A, Reina S, De Pinto V. VDAC1 as Pharmacological target in cancer and neurodegeneration: focus on its role in apoptosis. Front Chem. 2018;6:108.

137. Seo JH, Agarwal E, Chae YC, Lee YG, Garlick DS, Storaci AM, et al. Mitochondrial fission factor is a novel Myc-dependent regulator of mitochondrial permeability in cancer. EBioMedicine. 2019;48:353-63.

138. Tan W, Colombini M. VDAC closure increases calcium ion flux. Biochem Biophys Acta. 2007;1768:2510-5.

139. Mazure NM. VDAC in cancer. Biochim Biophys Acta. 2017;1858:665-73.

140. Keinan N, Pahima H, Ben-Hail D, Shoshan-Barmatz V. The role of calcium in VDAC1 oligomerization and mitochondria-mediated apoptosis. Biochem Biophys Acta. 2013;1833:1745-54.

141. Weisthal S, Keinan N, Ben-Hail D, ArifT, Shoshan-Barmatz V. Ca(2+)mediated regulation of VDAC1 expression levels is associated with cell death induction. Biochem Biophys Acta. 2014;1843:2270-81.

142. Shoshan-Barmatz V, Ben-Hail D. VDAC, a multi-functional mitochondrial protein as a pharmacological target. Mitochondrion. 2012;12:24-34.

143. Mahmoud MS, Ishikawa H, Fujii R, Kawano MM. Induction of CD45 expression and proliferation in U-266 myeloma cell line by interleukin-6. Blood. 1998;92:3887-97.

144. Sharaf el dein O, Gallerne C, Brenner C, Lemaire C. Increased expression of VDAC1 sensitizes carcinoma cells to apoptosis induced by DNA cross-linking agents. Biochem Pharmacol. 2012;83:1172-82.

145. Baughman JM, Perocchi F, Girgis HS, Plovanich M, Belcher-Timme CA, Sancak Y, et al. Integrative genomics identifies MCU as an essential component of the mitochondrial calcium uniporter. Nature. 2011:476:341-5.

146. De Stefani D, Raffaello A, Teardo E, Szabò I, Rizzuto R. A forty-kilodalton protein of the inner membrane is the mitochondrial calcium uniporter. Nature. 2011;476:336-40.

147. Marchi S, Pinton P. The mitochondrial calcium uniporter complex: molecular components, structure and physiopathological implications. J Physiol. 2014;592:829-39.
148. Kamer KJ, Sancak Y, Mootha VK. The uniporter: from newly identified parts to function. Biochem Biophys Res Commun. 2014;449:370-2.

149. Lee Y, Min CK, Kim TG, Song HK, Lim Y, Kim D, et al. Structure and function of the N-terminal domain of the human mitochondrial calcium uniporter. EMBO Rep. 2015;16:1318-33.

150. Orrenius S, Zhivotovsky B, Nicotera P. Regulation of cell death: the calcium-apoptosis link. Nat Rev Mol Cell Biol. 2003:4:552-65.

151. Landowski TH, Megli CJ, Nullmeyer KD, Lynch RM, Dorr RT. Mitochondrial-mediated disregulation of $\mathrm{Ca} 2+$ is a critical determinant of Velcade (PS-341/bortezomib) cytotoxicity in myeloma cell lines. Can Res. 2005;65:3828-36.

152. Song IS, Kim HK, Lee SR, Jeong SH, Kim N, Ko KS, et al. Mitochondrial modulation decreases the bortezomib-resistance in multiple myeloma cells. Int J Cancer. 2013;133:1357-67.

153. Ria R, Vacca A. Bone marrow stromal cells-induced drug resistance in multiple myeloma. Int J Mol Sci. 2020;21:613.

154. Vazquez G, Wedel BJ, Bird GS, Joseph SK, Putney JW. An inositol 1,4,5-trisphosphate receptor-dependent cation entry pathway in DT40 B lymphocytes. EMBO J. 2002;21:4531-8.

155. Glitsch MD, Bakowski D, Parekh AB. Store-operated Ca2+ entry depends on mitochondrial Ca2+ uptake. EMBO J. 2002;21:6744-54.

156. Dang D, Rao R. Calcium-ATPases: Gene disorders and dysregulation in cancer. Biochem Biophys Acta. 2016;1863:1344-50.

157. Vangheluwe P, Sepúlveda MR, Missiaen L, Raeymaekers L, Wuytack F, Vanoevelen J. Intracellular Ca2+- and Mn2+-transport ATPases. Chem Rev. 2009;109:4733-59.

158. Verkhratsky A. Physiology and pathophysiology of the calcium store in the endoplasmic reticulum of neurons. Physiol Rev. 2005;85:201-79.

159. Brini M, Cali T, Ottolini D, Carafoli E. Calcium pumps: why so many? Compr Physiol. 2012;2:1045-60.

160. Yadav J, Muend S, Zhang Y, Rao R. A phenomics approach in yeast links proton and calcium pump function in the Golgi. Mol Biol Cell. 2007;18:1480-9.

161. Roti G, Carlton A, Ross KN, Markstein M, Pajcini K, Su AH, et al. Complementary genomic screens identify SERCA as a therapeutic target in NOTCH1 mutated cancer. Cancer Cell. 2013;23:390-405.

162. Varga K, Hollósi A, Pászty K, Hegedús L, Szakács G, Tímár J, et al. Expression of calcium pumps is differentially regulated by histone deacetylase inhibitors and estrogen receptor alpha in breast cancer cells. BMC Cancer. 2018;18:1029.

163. Ribiczey P, Papp B, Homolya L, Enyedi Á, Kovács T. Selective upregulation of the expression of plasma membrane calcium ATPase isoforms upon differentiation and 1,25(OH)2D3-vitamin treatment of colon cancer cells. Biochem Biophys Res Commun. 2015;464:189-94.

164. Richardson DA, Sritangos P, James AD, Sultan A, Bruce JIE. Metabolic regulation of calcium pumps in pancreatic cancer: role of phosphofructokinase-fructose-bisphosphatase-3 (PFKFB3). Cancer Metab. 2020;8:2.

165. Monteith GR, Davis FM, Roberts-Thomson SJ. Calcium channels and pumps in cancer: changes and consequences. J Biol Chem. 2012;287:31666-73.

\section{Publisher's Note}

Springer Nature remains neutral with regard to jurisdictional claims in published maps and institutional affiliations. 